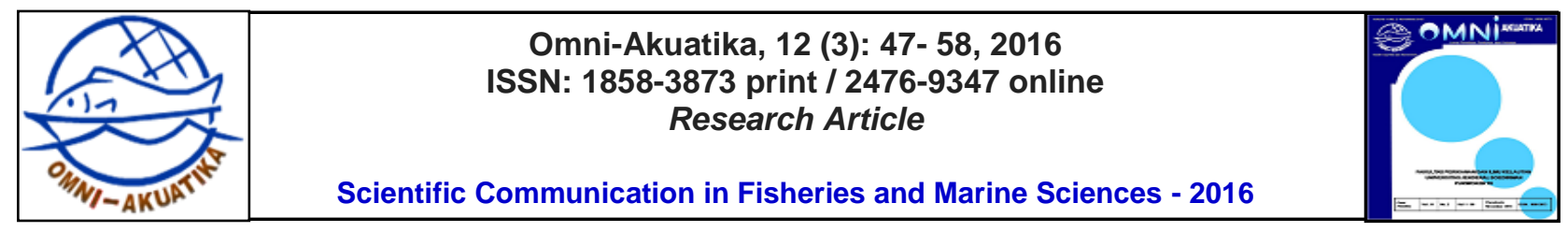

\title{
Pemetaan Habitat Ruaya Benih Ikan Sidat (Anguilla bicolor) dan Potensinya di Pantai Selatan Jawa
}

\author{
Haryono dan Gema Wahyudewantoro \\ Bidang Zoologi, Pusat Penelitian Biologi-LIPI, Jl. Raya Jakarta Bogor Km. 46 Cibinong 16911 \\ Corresponding author: ikharyono@yahoo.com
}

\begin{abstract}
The eels is fish commodities that interesting and prospective for cultured. For the fish fry supply still rely on catches of wild nature, one of them the south coast of Java. But the these habitat and abundance not yet to mapping The aims of this study to assess the conditions migration habitat of glass eel, abundance, identification of threats, and conservation efforts. The study used survey methods, glass eel catched with hand nets size $1 \times 1 \mathrm{~m}$, catching at night each 2 hours, the number of fisherman are three peoples. The results of the study recorded nine rivers and four of them potential as migration habitat of eels, habitat conditions are still good, the highest abundance is Cibuniangen river in the rainy season, the daily abundance was fluctuated and the highest at 3:00 a.m, identified several threats, conservation need integrated effort.
\end{abstract}

Keywords: eels, habitat, abundance, conservation

\section{Pendahuluan}

Sidat merupakan sumberdaya perikanan yang banyak menarik perhatian, baik dari kalangan peneliti maupun praktisi. Hal ini dikarenakan mempunyai siklus hidup yang unik, bergizi tinggi, dan bernilai ekonomis tinggi baik untuk pasar lokal maupun ekspor (Haryono, 2008). Daging sidat memiliki kandungan protein yang tinggi 16,4\% dan vitamin A sebesar 4700 IU (Pratiwi, 1998). Secara ekonomi, Hernando (2007) menyebutkan bahwa di Indonesia sidat belum menjadi makanan populer, sebaliknya di Jepang harganya sangat tinggi.

Indonesia berpotensi

untuk mengembangkan budidaya sidat karena mempunyai jenis ikan sidat yang beragam. Miller \& Tsukamoto (2004) melaporkan bahwa di dunia terdapat 18 jenis sidat, tujuh diantaranya ditemukan di perairan Indonesia (Sugeha et al. 2006). Jenis sidat yang sudah banyak dibudidayakan di Indonesia baru Anguilla bicolor (Peni, 1993). Jenis tersebut terbagi menjadi dua subspecies, yaitu $A$. bicolor bicolor dan A. bicolor pacifica (Watanabe et al., 2005).

Siklus hidup sidat sangat kompleks, salah satu tahapan yang menarik adalah perpindahan antara leptocephalus yang hidup di laut menjadi glass eel yang beruaya/bermigrasi memasuki perairan tawar (Davey \& Jellyman, 2005; Aida dalam Linton et al. 2007). Ikan sidat mempunyai kebiasaan hidup memijah di laut yang hangat pada kedalaman sekitar $400 \mathrm{~m}$ (Matsui, 1982). Benih sidat akan masuk muara sungai pada malam hari ketika pasang tinggi dan salinitas di muara sungai rendah (Matsui, 1982; Tesch, 2003; Dou \& Tsukamoto, 2003; Linton et al., 2007).

Tingginya tingkat penangkapan berakibat makin terancamnya ketersediaan benih sidat di alam. Diantaranya adalah penurunan hasil tangkapan sidat Eropa (Anguilla anguilla) yang tinggal 5-10\% dibandingkan tahun 1970an (ICES 2007 dalam Aalto et al. 2016). Bahkan jenis sidat ini sudah masuk dalam daftar Appendix II CITES (Charrier et al. 2012). Penurunan hasil tangkapan benih sidat secara drastis juga terjadi pada spesies sidat Amerika (Anguilla rostrata) dan sidat Jepang (Anguilla japonica) (Harisson et al. 2014). Kondisi serupa dapat menimpa terhadap sidat di Indonesia bila tidak dikelola dengan baik. Berkurangnya hasil tangkapan benih sidat dapat disebabkan oleh tingginya tingkat ekpsloitasi, menurunnya kualitas lingkungan berupa pencemaran air, sedimentasi, penambangan, dan dampak pembangunan lainnya. Oleh karena itu diperlukan identifikasi ancaman yang terdapat di sekitar habitat ruaya benih ikan sidat Indonesia.

Daerah penangkapan benih sidat di Indonesia terutama di pantai barat Sumatera 
dan pantai Selatan Jawa (Sutardjo \& Mahfudz, 1972; Affandi et al., 1995; Sarwono, 1999). Hal ini terkait dengan lokasi pemijahannya. Menurut Feunteun (2002), bahwa lokasi pemijahan sidat jenis $A$. bicolor salah satunya adalah di Samudera Indonesia bagian barat daya Sumatera.

Suplai benih sidat untuk kegiatan budidaya di Indonesia selama ini sebagian besar berasal dari hasil tangkapan di muara S. Cimandiri Pelabuhan Ratu. Namun saat ini telah beroperasi PLTU yang lokasinya tepat berada di tepian muara S. Cimandiri. Hal ini dikhawatirkan akan berdampak pada penurunan produksi hasil tangkapan benih sidat yang secara tidak langsung akan mengganggu kegiatan budidayanya. Dalam rangka menjaga ketersediaan pasokan benih sidat untuk mendukung keberlangsungan kegiatan budidaya maka diperlukan lokasi lain sebagai pemasok alternatif. Untuk itu telah dilakukan penelitian berupa pemetaan habitat ruaya ikan sidat khususnya di pantai selatan
Jawa. Tujuan penelitian ini mengkaji kondisi habitat ruaya, kelimpahan benih sidat (potensi), mengidentifikasi ancaman, dan upaya konservasinya.

\section{Metodologi}

Penelitian dilakukan di Jawa wilayah Provinsi Jawa Barat dan Banten pada sungaisungai yang bermuara ke pantai selatan Jawa. Pendataan lokasi-lokasi yang berpotensi sebagai habitat ruaya dilakukan melalui penelusuran peta, pustaka, dan dilanjutkan wawancara dengan masyarakat di sekitar lokasi tersebut. Lokasi yang dimaksud untuk wilayah Banten meliputi S.Bayah, S. Cibunangeun, S. Ciliman, dan S. Bungur. Di wilayah Sukabumi adalah S. Cikaso, S. Cibuni, dan S. Cimaja. Adapun di Garut meliputi S. Cibalebeuh, S. Cipasarangan, S. Pameungpeuk, dan S. Cisanggiri (Tabel 1 dan Gambar 1).

Tabel 1. Lokasi dan koordinat habitat ruaya benih ikan sidat

\begin{tabular}{|c|c|c|}
\hline Stasiun & Lokasi & Koordinat \\
\hline St.1 & $\begin{array}{l}\text { S. Cibinuangeun, Desa. Muara, Kec. } \\
\text { Wanasalam, Kab. Lebak-Banten }\end{array}$ & $\mathrm{S}: 06^{\circ} 50.395$ dan $\mathrm{E}: 105^{\circ} 52.891$ \\
\hline St.2 & $\begin{array}{l}\text { S. Ciliman, JI. Raya Tanjung Lesung } \\
\text { (Panimbang), Desa Sidamukti, Kec. } \\
\text { Sukaresmi, Kab. Pendeglang }\end{array}$ & $\mathrm{S} 06^{\circ} 29.455$ dan E $105^{\circ} 47.847$ \\
\hline St.3 & $\begin{array}{l}\text { S. Bungur, Desa Sidamukti, Kec. Sukaresmi, } \\
\text { Kab. Pendeglang }\end{array}$ & $\mathrm{S} 06^{\circ} 26.222$ dan E $105^{\circ} 49.514$ \\
\hline St.4 & $\begin{array}{l}\text { S. Bayah, Desa Bayah, Kec. Bayah, Kab. } \\
\text { Lebak }\end{array}$ & $\mathrm{S} 06^{\circ} 56.385$ dan E $106^{\circ} 14.833$ \\
\hline St.5 & $\begin{array}{l}\text { S. Cibuni, Desa Tegal Bulet, Kec. Tegal } \\
\text { Bulet, Kab. Sukabumi }\end{array}$ & $\mathrm{S} 07^{\circ} 26.102$ dan E $106^{\circ} 47.469$ \\
\hline St.6 & $\begin{array}{l}\text { S. Cimaja, Desa Cimaja, Kab. Cimaja, Kab. } \\
\text { Sukabumi }\end{array}$ & $\mathrm{S} 06^{\circ} 57.704$ dan E $106^{\circ} 28.901$ \\
\hline St.7 & $\begin{array}{l}\text { S. Cibalebeuh, Desa Mandala Kasih, Kec. } \\
\text { Pameungpeuk, Kab. Garut }\end{array}$ & $\mathrm{S} 07^{\circ} 40.188$ dan E $107^{\circ} 44.461$ \\
\hline St.8 & $\begin{array}{l}\text { S. Cipasarangan, Desa Cikelet, Kec. Cikelet, } \\
\text { Kab. Garut }\end{array}$ & $\mathrm{S} 07^{\circ} 37.388$ dan E $107^{\circ} 40.184$ \\
\hline St.9 & $\begin{array}{l}\text { S. Gunung Sula, Desa Cigadog, Kec. Cikelet, } \\
\text { Kab. Garut }\end{array}$ & $\mathrm{S} 07^{\circ} 36.575$ dan E $107^{\circ} 39.283$ \\
\hline
\end{tabular}




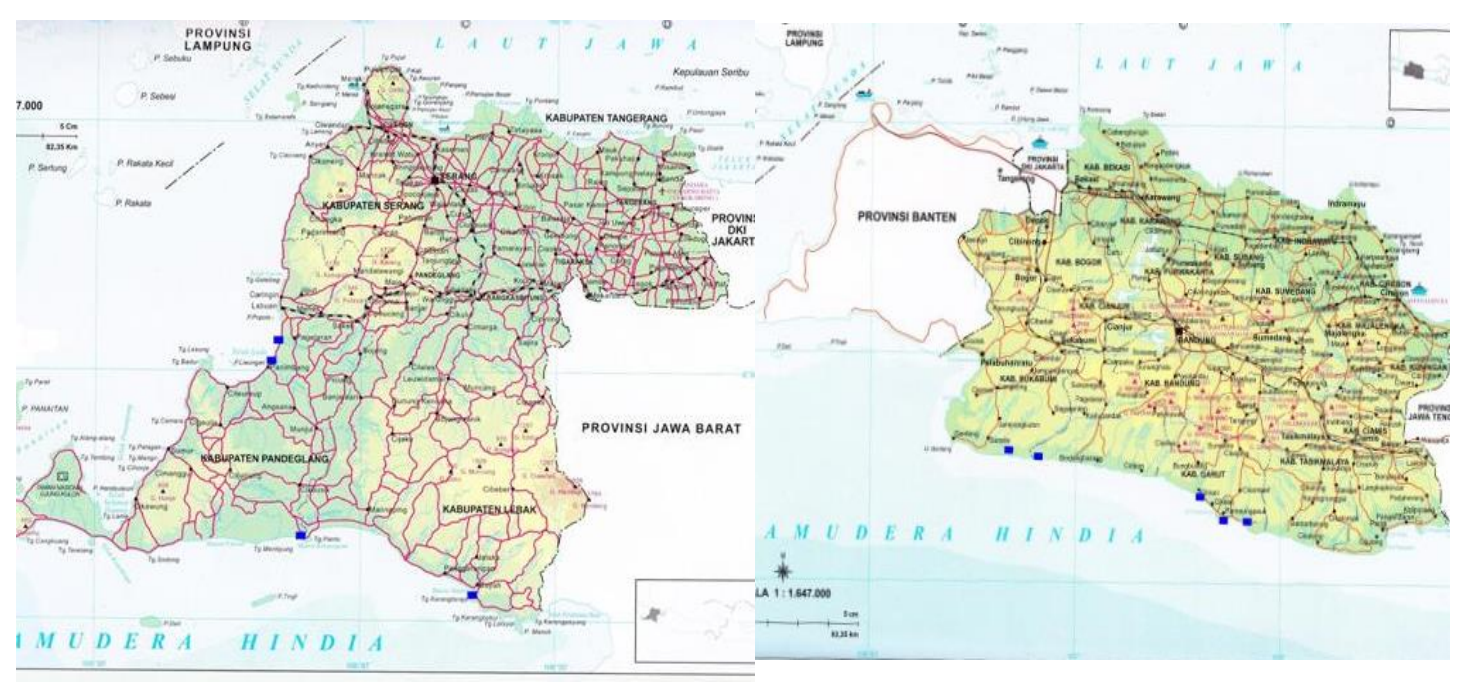

Gambar 1. Peta lokasi habitat ruaya ikan sidat di Provinsi Banten dan Jawa Barat

Pengamatan kondisi habitat berupa parameter fisika dan kimia pada setiap stasiun dilakukan secara langsung di lokasi penelitian dan juga melalui pengambilan sampel air. Parameter yang diamati meliputi salinitas, kekeruhan, kandungan oksigen terlarut, tingkat keasaman $(\mathrm{pH})$, kecepatan arus, suhu air, kedalaman air, alkalinitas, amonia, dan parameter terkait lainnya. Selain itu diidentifikasi jenis-jenis ancaman yang membahayakan kelestarian benih sidat. Hal ini penting sebagai bahan pertimbangan dalam perencanaan untuk pengelolaan dan konservasi sumberdaya benih sidat.

Untuk menentukan stasiun yang potensial sebagai sumber benih sidat ditentukan berdasarkan kelimpahan dari hasil pengambilan sampel benih sidat. Pengambilan sampel diawali pada musim kemarau sebanyak 9 stasiun, sedangkan pada musim penghujan hanya dilakukan pada stasiun terpilih. Alat dan teknik pengambilan sampel benih sidat sebagai berikut:

- alat tangkap yang digunakan hanco ukuran $1 \times 1 \mathrm{~m}$ dengan mesh size 1 $\mathrm{mm}$ yang terbuat dari bahan nilon halus

- alat penerangan menggunakan lampu petromax berbahan bakar minyak tanah

- waktu pengambilan sampel pada bulan gelap mulai pukul 19.00 sampai 05.00 dengan jeda waktu dua jam sekali

- lokasi pengambilan sampel pada muara sungai terpilih di pantai selatan Jawa
- Pengambilan sampel dilakukan oleh tiga orang

- Jumlah angkatan hanco 100 kali per orang per waktu dengan total angkatan 600 kali per orang, atau 1.800 angkatan per malam

Benih sidat yang tertangkap dihitung jumlahnya pada setiap angkatan, lalu dihitung jumlahnya per waktu pengamatan. Data total hasil tangkapan di setiap lokasi selanjutnya dianalisis tingkat kemelimpahannya sebagai dasar pertimbangan untuk menentukan potensinya.

\section{Hasil dan Pembahasan}

Kondisi habitat ruaya

Ruaya atau migrasi benih sidat dari laut ke perairan tawar dipengaruhi oleh banyak faktor, diantaranya adalah kondisi lingkungan muara sungai (Matsui, 1982; Harrison et al., 2014). Hasil pengamatan terhadap kondisi lingkungan dari seluruh stasiun yang diteliti mempunyai kisaran suhu air antara $22-29^{\circ} \mathrm{C}$, $\mathrm{pH}$ antara 7-7,5; kedalaman air ketika surut antara $30-75 \mathrm{~cm}$, lebar muara sungai antara 30-150 m, warna air jernih sampai keruh, kecepatan arus umumnya sedang, dasar perairan kebanyakan berupa pasir, sedangkan yang batuan hanya dijumpai di muara sungai Cimaja, Gunung Sula, dan Cipasarangan (Tabel 2). 
Tabel 2. Kisaran hasil pengamatan parameter fisika-kimia di lokasi penelitian

\begin{tabular}{clc}
\hline No. & Parameter & Kisaran \\
\hline 1 & Suhu air & $22-29^{\circ} \mathrm{C}$ \\
2 & pH air & $7.0-7.5$ \\
3 & Kedalaman air pada saat surut & $30-75 \mathrm{~cm}$ \\
4 & Lebar muara sungai & $30-150 \mathrm{~m}$ \\
5 & Warna air & jernih - keruh \\
6 & Kecepatan arus & Lamat-sedang \\
7 & Dasar perairan & pasir dan batuan \\
\hline
\end{tabular}

Berdasarkan hasil pengamatan di atas menunjukkan bahwa kondisi lingkungan di lokasi tersebut masih cukup baik untuk mendukung proses ruaya benih sidat. Hal ini mengacu kepada Pescod (1973) dan Anonim (1992) bahwa kisaran kualitas air yang baik untuk kehidupan ikan dan biota akuatik lainnya yaitu suhu air $<30^{\circ} \mathrm{C}$ dan $\mathrm{pH}$ antara 6 - 8,5. Perubahan suhu air sangat berpengaruh terhadap kehidupan ikan. Sebagaimana disebutkan oleh Effendi (2003) bahwa peningkatan suhu akan menyebabkan peningkatan proses respirasi dan metabolisme hewan air, sebaliknya akan menurunkan difusi oksigen ke dalam air.

Dalam proses ruaya benih sidat ke perairan tawar, suhu merupakan faktor lingkungan yang sangat berpengaruh (Kim et al., 2006; Harrison et al., 2014). Menurut Linton et al. (2007), suhu berpengaruh terhadap aktivitas benih sidat terkait dengan gerakan berenang maupun loncat. Suhu yang baik untuk berenang maupun loncat di daerah empat musim antara $17-25^{\circ} \mathrm{C}$. Perubahan suhu pada malam hari yang lebih dingin berasosiasi dengan faktor minimnya cahaya menyebabkan aktivitas ruaya lebih banyak terjadi pada malam hari. Selanjutnya Dou \& Tsukamoto (2003) melaporkan bahwa pada kondisi laboratorium benih sidat secara nyata cenderung aktif pada malam hari (nokturnal). Pada saat terang, benih sidat lebih banyak berlindung dengan sedikit makan dan sebaliknya akan meningkat pada saat gelap. Oleh karena itu pengambilan sampel benih sidat pada penelitian ini dilakukan malam hari.

Hasil pengamatan terhadap kondisi lingkungan di sekitar sungai yang menjadi tempat ruaya benh sidat, sebagian besar berupa areal pertanian mulai dari persawahan, ladang, perkebunan, dan diselingi oleh pemukiman penduduk. Bahkan di sekitar muara S. Cibuni terhampar lahan marginal yang sangat luas. Lahan marginal tersebut baru dimanfaatkan sebagai tempat penggembalaan sapi dan kerbau, dan hanya sebagian kecil yang ditanami buah semangka. Dengan demikian habitat ruaya tersebut masih relatif aman karena tidak ditemukan industri/pabrik yang berpeluang membuang limbahnya langsung ke perairan sungai.

Hasil analisis sampel air di laboratorium yaitu alkalinitas 60,24 - 155,62 ppm, kesadahan 37,8 - 314,16 ppm, amonia 0,03 $0,286 \mathrm{ppm}$, karbondioksida 0,93 - 9,2, kekeruhan 0,019-0,390 NTU, dan air raksa < 0,81 (Tabel 3). Berdasarkan hasil pengamatan menunjukkan bahwa kondisi muara-muara sungai tersebut secara umum masih cukup baik. Kisaran tersebut masih dalam batas optimal dengan kriteria untuk amonia $<2 \mathrm{ppm}$, kesadahan $<100 \mathrm{ppm}$, kekeruhan $<100 \mathrm{NTU}$, nitrat $<10 \mathrm{ppm}$, dan karbondioksida < 12 ppm (Pescod, 1973; Anonim, 1982; Effendi, 2003). Selanjutnya Kim et al. (2006) menyebutkan bahwa pada saat beruaya ke sungai, benih sidat beradaptasi secara fisiologi pada sistem osmoregulasi terkait dengan perubahan salinitas. Hal ini sejalan dengan Tesh (2003) yang menyebutkan bahwa benih sidat akan bermigrasi memasuki perairan tawar pada saat salinitas di muara sungai relatif rendah. Selanjutnya Harrison et al. (2014) bahwa migrasi benih sidat terjadi sepanjang tahun, faktor yang berpengaruh antara lain curah hujan dan pasang surut. Hal ini secara tidak langsung berkaitan dengan salinitas. Adapun kisaran salinitas di lokasi penelitian antara 0,1-11,4 sehingga masih dapat ditolerir oleh benih sidat. 
Tabel 3.Kisaran hasil analisis laboratorium sampel air

\begin{tabular}{lllcc}
\hline No. & \multicolumn{1}{c}{ Parameter } & Satuan & \multicolumn{2}{c}{ Musim } \\
\cline { 4 - 5 } & & & Penghujan & Kemarau \\
\hline 1 & Alkalinitas & ppm & $61,27-114,36$ & $60,24-155,62$ \\
2 & Kesadahan & ppm & $61,2-31, .16$ & $37,8-189,00$ \\
3 & Amonia & ppm & $0,052-0,127$ & $0,03-0,286$ \\
4 & Karbondioksida & ppm & $3,95-9,2$ & $0,93-2,79$ \\
5 & Air raksa & ppb & $<0,81$ & - \\
6 & Kekeruhan & NTU & $0,019-0,390$ & - \\
7 & Salinitas & permil & $0,1-11,4$ & $0,1-11,1$ \\
\hline
\end{tabular}

Dari hasil pengamatan secara fisik dapat diketahui bahwa sungai yang muaranya memiliki dasar perairan berupa pasir dengan kedalaman air yang relatif tinggi dan tidak terlalu lebar lebih potensial sebagai sumber benih sidat (S. Bayah dan S. Cikaso). Sebaliknya muara sungai yang lebar dan dangkal, serta mempunyai dasar perairan batuan kurang potensial. Hal ini dapat dibandingkan antara S. Cimaja dan S. Bungur yang keduanya mempunyai lebar muara hampir sama; muara S. Cimaja kurang potensial dibandingkan S. Bungur karena dasar perairannya berupa batuan berukuran besar (diameter 20-40 cm), sedangkan di S. Bungur berupa campuran antara pasir dan lumpur. Namun demikian untuk mengetahui preferensi habitat benih sidat harus dikaji lebih lanjut karena banyak faktor lingkungan yang berpengaruh.

Dalam pemetaan lokasi yang potensial sebagai sumber benih sidat dilakukan dengan mengacu pendapat Matsui (1982) bahwa sidat melakukan pemijahan di kedalaman sekitar 400 meter. Hal ini mengisyaratkan bahwa diantara lokasi di Indonesia yang merupakan tempat pemijahan ikan sidat adalah Samudera Indonesia. Selain itu, disebutkan bahwa daerah penangkapan benih sidat terutama adalah pantai barat Sumatera dan Selatan Jawa, terutama sekitar Pelabuhan Ratu dan Cilacap (Sutardjo dan
Mahfudz, 1972; Affandi et al., 1995; Sarwono, 1999). Selanjutnya pengumpul benih sidat (Engkan, Komunikasi Pribadi) menyebutkan bahwa benih sidat dapat ditemukan di sepanjang pesisir pantai selatan Jawa terutama pada muara-muara sungai yang cukup besar. Kondisi lingkungan dan ukuran muara sungai tersebut sangat menentukan terjadinya proses ruaya, semakin baik kondisinya akan semakin tinggi kelimpahan benih sidatnya. Muara sungai yang potensial sebagai habitat ruaya setidaknya berukuran di atas 25 meter pada saat air laut pasang. Pada Tabel 2 dapat dilihat bahwa kisaran lebar sungai di lokasi penelitian antara 30-150 meter sehingga sebagian besar sungai tersebut memungkinkan sebagai tempat ruaya benih sidat.

\section{Kelimpahan benih sidat (potensi)}

Hasil pengamatan terhadap kelimpahan benih sidat pada beberapa sungai di pantai selatan Jawa sangat bervariasi. Pada musim kemarau terdapat empat sungai yang total hasil tangkapan per malam cukup besar, yaitu Bungur (24 ekor), Bayah (24 ekor), Cibuniangeun 118 ekor), dan Cibuni (295 ekor). Adapun yang kelimpahannya rendah (2-3 ekor) dijumpai di tiga sungai yaitu Cimaja, Cipasarangan, dan Gunung Sula (Tabel 4). 
Tabel 4. Hasil tangkapan benih sidat pada musim kemarau

\begin{tabular}{cccccccccc}
\hline $\begin{array}{c}\text { Waktu } \\
\text { Sampli } \\
\text { ng }\end{array}$ & $\begin{array}{c}\text { Cibuniang } \\
\text { eun }\end{array}$ & $\begin{array}{c}\text { Cilim } \\
\text { an }\end{array}$ & $\begin{array}{c}\text { Bung } \\
\text { ur }\end{array}$ & $\begin{array}{c}\text { Bay } \\
\text { ah }\end{array}$ & $\begin{array}{c}\text { Cibu } \\
\text { ni }\end{array}$ & $\begin{array}{c}\text { Cima } \\
\text { ja }\end{array}$ & $\begin{array}{c}\text { Cibaleb } \\
\text { uh }\end{array}$ & $\begin{array}{c}\text { Cipasaran } \\
\text { gan }\end{array}$ & $\begin{array}{c}\text { Gunu } \\
\text { ng } \\
\text { Sula }\end{array}$ \\
\hline 19.00 & 16 & 0 & 0 & 6 & 11 & 1 & 0 & 3 & 2 \\
21.00 & 2 & 0 & 10 & 4 & 112 & 0 & 0 & 0 & 0 \\
23.00 & 26 & 0 & 9 & 7 & 93 & 0 & 0 & 0 & 0 \\
01.00 & 66 & 0 & 3 & 2 & 45 & 0 & 0 & 0 & 0 \\
03.00 & 3 & 0 & 1 & 1 & 26 & 0 & 0 & 0 & 0 \\
05.00 & 5 & 0 & 1 & 4 & 8 & 1 & 0 & 0 & 0 \\
\hline $\begin{array}{c}\text { Total } \\
\text { (ekor) }\end{array}$ & 118 & 0 & 24 & 24 & 295 & 2 & 0 & 3 & 2 \\
\hline
\end{tabular}

Pada musim penghujan terdapat empat sungai yang banyak tertangkap benih sidat, yaitu Cibuni (191 ekor), Bayah (244 ekor), Cibuniangeun sebanyak (601 ekor), dan Cikaso (527 ekor) (Tabel 5).

Tabel 5. Hasil tangkapan benih sidat pada musim penghujan

\begin{tabular}{ccccccc}
\hline Waktu & \multicolumn{5}{c}{ Lokasi Penelitian } \\
\cline { 2 - 7 } (Pukul) & Cibuniangeun & Ciliman & Bungur & Bayah & Cibuni & Cikaso \\
\hline 19.00 & 0 & 0 & 0 & 3 & 9 & 92 \\
21.00 & 106 & 0 & 0 & 2 & 38 & 125 \\
23.00 & 88 & 0 & 0 & 4 & 88 & 96 \\
01.00 & 124 & 0 & 0 & 27 & 15 & 99 \\
03.00 & 280 & 0 & 0 & 121 & 33 & 73 \\
05.00 & 3 & 0 & 0 & 87 & 8 & 42 \\
\hline Total (ekor) & 601 & 0 & 0 & 244 & 191 & 527 \\
\hline
\end{tabular}

Pada Tabel 4 dapat dilihat bahwa terdapat dua lokasi yang sama sekali tidak ditemukan benih sidat pada musim kemarau, yaitu S. Ciliman dan S. Cibalebuh. Pada sungai Ciliman diduga karena telah terjadi perubahan lingkungan di sekitar sungai yang cukup drastis berupa pemukiman padat penduduk sehingga tidak memungkinkan lagi untuk proses ruaya ikan sidat, Sedangkan pada S. Cibalebuh akibat dibangun tanggul pemecah ombak sehingga arus air di muara sungai tidak alami lagi. Hal yang hampir serupa terjadi di $\mathrm{S}$. Bungur dimana pada musim penghujan gelombangnya besar sehingga tidak ditemukan benih sidat, padahal pada musim kemarau ditemukan. Matsui (1982) menyebutkan bahwa faktor lingkungan yang berpengaruh terhadap ruaya benih ikan sidat ke sungai, diantaranya kecepatan angin dan pasang surut air laut. Kedua faktor tersebut secara tidak langsung berkaitan dengan gelombang air laut, dimana semakin besar gelombang semakin sedikit benih sidat yang memasuki sungai.

Beberapa sungai mempunyai tingkat kelimpahan yang cukup tinggi sehingga sangat potensial sebagai lokasi penangkapan benih sidat. Sungai yang dimaksud adalah Cibuniangeun dengan kelimpahan 118 ekor pada musim kemarau dan 601 ekor pada musim penghujan; S. Cibuni 295 ekor pada musim kemarau dan 191 ekor pada musim hujan; S. Bayah 24 ekor pada musim kemarau dan 244 ekor pada musim penghujan (Tabel 4 dan Tabel 5). Ketiga sungai tersebut memang telah dijadikan lokasi penangkapan benih sidat sejak beberapa tahun yang lalu. Namun kelimpahan di semua sungai tersebut masih lebih rendah jika dibandingkan dengan S. Cimandiri yang sudah sejak lama menjadi sentra penangkapan benih sidat dengan kisaran 738.416 ekor per malam; kelimpahan tertinggi dijumpai pada bulan November yang 
termasuk musim penghujan (Haryono et al. 2010).

Di S. Bayah terjadi perbedaan hasil tangkapan benih sidat yang signifikan antara musim kemarau dengan penghujan. Perbedaan ini diduga karena terjadi perubahan alur sungai yang lebih menguntungkan bagi ruaya benih sidat. Sebaliknya perubahan alur sungai yang terjadi di muara S. Cibuni berdampak negatif sehingga hasil tangkapan pada musim penghujan lebih rendah dibandingkan musim kemarau. Jika mengacu ke Matsui (1982), rendahnya hasil tangkapan di Sungai Cibuni ketika musim penghujan selain karena perubahan alur di muara sungai juga karena kencangnya angin dan besarnya gelombang laut.

Sungai Cikaso dipilih sebagai stasiun pengamatan pada musim penghujan karena berdasarkan informasi nelayan dan pengumpul menyebutkan bahwa sungai ini merupakan salah satu habitat ruaya benih sidat yang cukup potensial. Hasil pengamatan menunjukkan bahwa Cikaso memang menjadi habitat yang baik bagi ikan sidat. Ukuran benih sidat yang tertangkap lebih besar dibandingkan dengan hasil tangkapan di sungai lainnya. Hal ini disebabkan titik penangkapan di Cikaso bukan lagi berada di muara sungai tetapi jauh masuk ke dalam yaitu lebih dari $10 \mathrm{~km}$. Padahal kemampuan benih sidat untuk beruaya hanya berkisar antara 2-3 km per hari (Harrison et al., 2014). Dengan demikian benih sidat yang tertangkap di Cikaso sudah lebih tua 3-5 hari dibandingkan dengan lokasi lainnya. Selain ukurannya yang lebih besar juga warnanya sudah berubah menjadi kemerahan.

Kelimpahan harian benih sidat dalam semalam mengalami flukutuasi. Faktor yang memengaruhi diantaranya pasang surut air laut (Matsui, 1982; Harrison et al., 2014). Hasil pengamatan menunjukkan bahwa pada musim kemarau di S. Cibuniangeun puncak ruaya benih sidat terjadi pada pukul 01 sebanyak 66 ekor dan terus menurun sampai pagi; sedangkan di S. Cibuni mengalami puncaknya pada pukul 21.00 sebanyak 112 ekor dan juga cenderung menurun sampai pagi (Tabel 4). Namun pada musim penghujan puncak kelimpahan di keempat sungai (Cibuni, Bayah, Cibuniangeun, dan Cikaso) terjadi serentak pada pukul 03 (Gambar 3). Hal ini disebabkan pasang air laut yang tinggi terjadi sekitar pukul 02, dan puncak ruaya akan terjadi 1-2 jam setelah pasang tertinggi. Kondisi serupa juga dijumpai di S. Cimandiri dengan kelimpahan tertinggi ketika musim penghujan yaitu pukul 03.00 (Haryono et al. 2010).

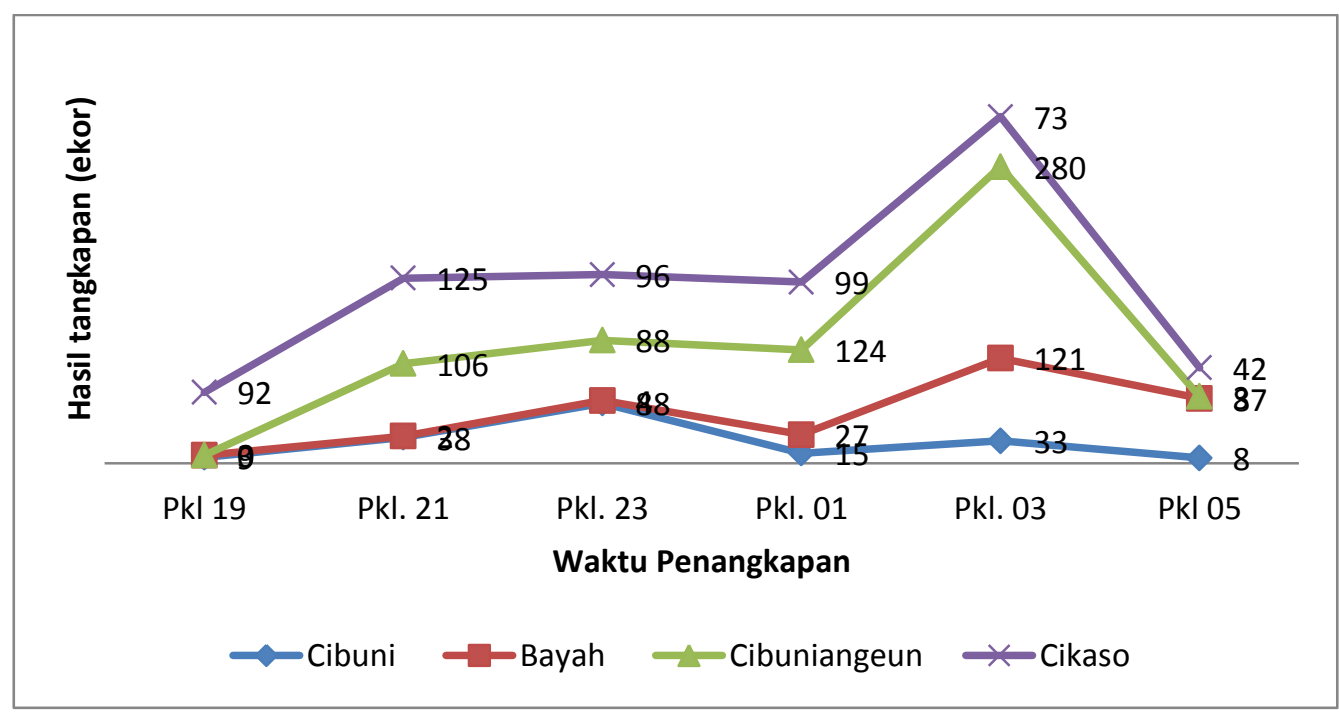

Gambar 3. Fluktuasi harian benih sidat di empat sungai pada musim penghujan 
Berdasarkan hasil penelitian diketahui bahwa lokasi yang diamati sebagian besar merupakan habitat ruaya. Lokasi yang dimaksud antara lain Cibuniangeun, Bungur, Bayah, Cibuni, Cimaja, Cipasarangan, dan Gunung Sula. Terdapat satu lokasi yang tidak lagi sebagai habitat ruaya ikan sidat, yaitu muara sungai Ciliman (St.2) karena selama pengamatan sama sekali tidak ditemukan benih sidat. Padahal lokasi tersebut pada tahun 1980an merupakan habitat ruaya ikan sidat (Engkan, Komunikasi Pribadi). Tidak terdapatnya benih sidat di muara S. Ciliman pada penelitian ini diduga karena lokasi tersebut sudah mengalami perubahan/penurunan kualitas lingkungan yang sangat drastis. Pada saat pengamatan, di sekitar muara sungai Ciliman merupakan daerah pemukiman yang padat penduduk, terdapat pasar dengan jumlah sampah yang tinggi, serta sebagai sarana lalu lintas nelayan untuk pulang pergi ke laut dengan intensitas tinggi.

Tingkat kelimpahan benih sidat di semua sungai yang diamati pada kedua musim termasuk rendah. Hal ini diduga karena pada saat pengamatan, curah hujan masih sangat tinggi yang mengakibatkan arus sungai di bagian muara cukup besar sehingga benih sidat tidak mampu beruaya memasuki perairan sungai. Menurut Matsui (1982), proses ruaya benih sidat selain dipengaruhi oleh pasang surut air laut juga sangat tergantung dengan curah hujan. Curah hujan secara tidak langsung akan berpengaruh terhadap arus, salinitas dan suhu air.

\section{Identifikasi jenis ancaman}

Hasil pengamatan terhadap aktivitas manusia (antropogenik) yang diduga dapat mengancam keberlangsungan proses ruaya ikan sidat sangat beragam, salah satunya adalah penambangan pasir. Aktivitas ini terjadi hampir di semua muara sungai yang dilakukan secara intensif. Lokasi penambangan antara lain muara sungai Cikaso, Cibuni, dan Cipasarangan. Bahkan di sekitar muara S. Cikaso terjadi penambangan pasir besi dengan skala besar dan intensif. Jika hal ini tidak dilakukan pengawasan maka akan berpengaruh terhadap kontur muara sungai yang pada akhirnya dapat mengganggu proses ruaya benih sidat. Padahal S. Cikaso dan Cibuni merupakan habitat ruaya benih sidat yang cukup potensial.

Selain penambangan pasir, ditemukan pula kegiatan penambangan batu dengan skala yang intensif karena menggunakan alat berat, yaitu di sekitar muara sungai Cimaja. Dampak kegiatan penambangan ini sangat jelas yaitu sering terjadi perubahan warna air dari jernih tiba-tiba menjadi keruh ketika aktivitas penambangan sedang berlangsung. Oleh karena itu hasil tangkapan benih sidat di Sungai Cimaja sangat minim. Padahal secara geografis S. Cimaja relatif berdekatan dengan S. Cimandiri yang merupakan sentra penangkapan benih sidat di pantai selatan Jawa.

Seiring dengan perkembangan kegiatan budidaya ikan sidat di Indonesia telah terjadi permintaan benih yang meningkat tajam. Hal ini berimbas pada peningkatan kegiatan eksploitasi/penangkapan sumberdaya ikan sidat. Semula target penangkapan oleh nelayan dan pengumpul hanya benih sidat ukuran glass eel, namun mulai awal tahun 2010 permintaan terhadap benih sidat beragam ukuran dari glass eel sampai fingerling (sejari). Sebagai gambaran permintaan benih sidat dari satu pembudidaya saja untuk tahun 2010 mencapai 2 juta ekor yang berukuran sejari. Salah satu buktinya adalah banyaknya stok benih ukuran sejari di tempat para pengumpul (Gambar 4). Meningkatnya permintaan ini merupakan dampak dari pengetatan aturan mengenai larangan ekspor benih sidat dengan ukuran di bawah $100 \mathrm{~g}$ (Permen KP Nomor 18 Tahun 2009). Bila penangkapan ikan sidat dengan berbagai ukuran terus dilakukan maka proses pertumbuhan dan regenerasi populasi ikan sidat menjadi terganggu, bahkan dapat terhenti karena tidak ada lagi individu yang tumbuh menjadi calon indukan.

Penangkapan ikan sidat ukuran sejari dilakukan menggunakan alat yang mirip dengan pukat harimau (trawl). Teknik penangkapan dengan cara memasang jaring trawl pada anak-anak sungai yang mengalir ke sungai utama ketika air sedang surut. Sasaran dari penangkapan ini terutama ikan sidat ukuran sejari ke atas beserta jenis ikan lainnya. Anakan sidat yang tertangkap dijual kepada pengumpul yang sudah biasa menangani sidat sejak lama. Teknik penangkapan seperti ini tentu akan menguras stok benih sidat yang hidup pada rawa-rawa di sekitar sungai. 


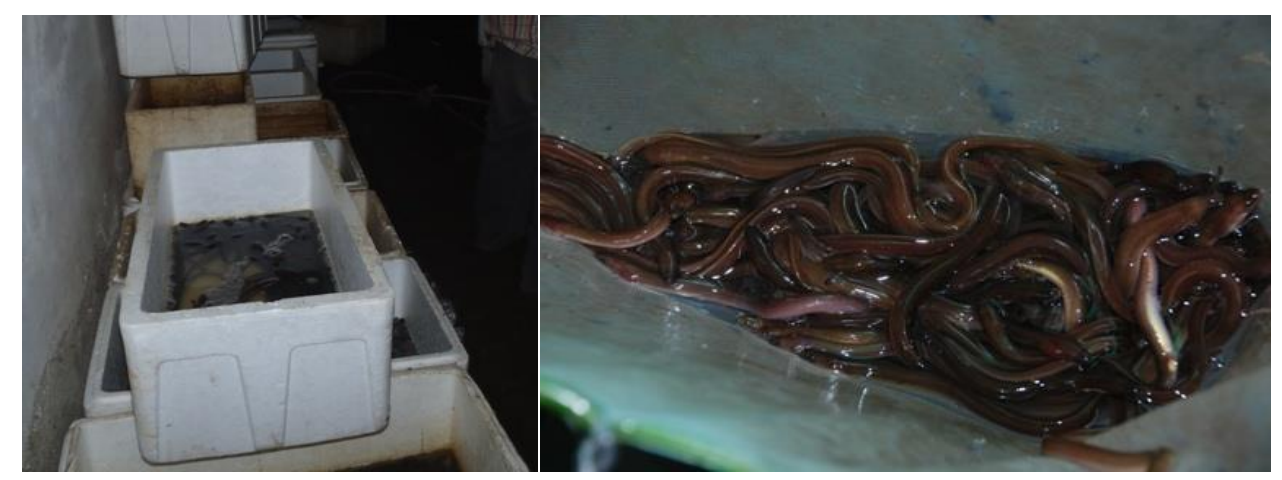

Gambar 4. Stok benih ukuran sejari di tempat pengumpul

Ancaman berikutnya adalah aktivitas lalu lintas perahu motor yang keluar masuk melalui muara sungai yang intensitasnya tinggi, terlebih lagi bila di lokasi tersebut padat penduduk. Beban sungai menjadi berat baik dari limbah rumah tangga maupun perahu motor, akibatnya ruaya benih ikan sidat di lokasi tersebut tidak ditemukan lagi. Salah satu contohnya ada;ah Sungai Ciliman. Bandingkan dengan muara S. Cimandiri yang lalu lintasnya tidak terlalu tinggi dan tidak ada pemukiman padat penduduk di sekitar muara sehingga ruaya ikan sidat tetap berlangsung.

Jenis ancaman yang juga teridentifikasi adalah pembuangan sampah dan limbah domestik yang telah menjadi pemandangan yang umum di beberapa muara sungai yang diamati. Jenis sampah terdiri dari kantung plastik, botol bekas minuman, bola lampu, dan yang lainnya. Bila sedang terjadi banjir di bagian hulu sungai maka sampah tersebut terbawa ke muara dan tampak berserakan ketika air laut surut. Kondisi seperti ini tentu akan mengganggu kelancaran proses ruaya benih sidat dari laut untuk memasuki perairan sungai.

\section{Upaya konservasi}

Salah satu upaya konservasi mengenai ikan sidat melalui regulasi adalah diterbitkannya Peraturan Menteri Kelautan dan Perikanan Nomor 18 Tahun 2009 yang melarang ekspor ikan sidat ukuran di bawah $100 \mathrm{~g}$ dan atau berdiameter $2,5 \mathrm{~cm}$. Hal ini berdampak positif dengan berdatangannya para investor yang begerak di bidang budidaya sidat ke Indonesia. Secara tidak langsung membuka peluang usaha baru dan kesempatan kerja di sektor perikanan. Namun di sisi lain telah meningkatkan permintaan pasokan benih sidat secara drastis. Akibatnya target penangkapan bukan hanya benih ukuran glass eel tetapi juga yang sejari. Lokasi penangkapan juga merambah ke tempat yang lebih luas mulai dari muara sungai sampai ke bagian tengah (hilir). Fenomena seperti ini dikhawatirkan dapat mengancam kelestarian ikan sidat karena tidak memberikan kesempatan benih sidat untuk tumbuh menjadi dewasa. Padahal sidat merupakan ikan yang unik karena dalam siklus hidupnya melakukan ruaya antara perairan tawar dan laut (Effendie, 2002). Pada tahap anakan sampai dewasa hidup di perairan tawar namun untuk pemijahannya ikan ini harus beruaya ke laut dalam.

Penegakan atauran larangan ekspor benih ikan sidat sebagaimana yang tertera dalam Peraturan Menteri Kelautan dan Perikanan Nomor 18 Tahun 2009 harus dilakukan. Hal ini perlu dipeketat karena sumber benih sidat di wilayah Indonesia menjadi incaran banyak negara. Jika tidak dikelola dengan baik maka populasinya di alam dapat mengalami penurunan secara drastis, sebagaimana yang terjadi pada sidat Eropa (Anguilla anguilla), sidat Jepang (Anguilla japonica), dan sidat Amerika (Anguilla rostrata) (Harrison et al. 2014). Pengawasan terhadap kegiatan ekspor ikan ini perlu diawasi secara ketat agar tidak terjadi kebocoran.

Untuk mencegah penurunan populasi ikan sidat di alam, kegiatan penangkapan perlu dilakukan pembatasan sesuai dengan kebutuhan untuk budidayanya. Untuk itu perlu adanya pendataan jumlah pembudidaya dan kapasitas usahanya sehingga dapat diperkirakan total kebutuhan benih per tahunnya. Dengan demikian tidak lagi terjadi pemborosan benih akibat penangkapan yang 
berlebihan. Selain itu, untuk menekan keperluan benih sidat dapat ditempuh melalui peningkatan teknik penanganan dan pemeliharaan tahap awal agar mortalitas dapat ditekan. Selama ini banyak terjadi mortalitas benih sidat pada tahap awal pemeliharaan yang umumnya di atas 50\%. Penanganan benih sidat agar mortalitas dapat ditekan mencakup penanganan ketika baru ditangkap, packing, pengangkutan, sampai pemeliharaan tahap awal (Haryono et al. 2011; Wahyudewantoro et al. 2011).

Aktivitas penangkapan ikan sidat tidak hanya terhadap ukuran benih tetapi juga ukuran dewasa yang sedang beruaya menuju ke laut untuk memijah. Alat tangkap yang digunakan banyak yang tidak ramah lingkungan. Untuk itu perlu dilakukan pemulihan populasi ikan sidat, salah satunya melalui kegiatan restoking. Menurut Sadili et al. (2015), restoking merupakan bagian dari upaya pengkayaan populasi ikan di suatu perairan tertentu dimana jenis ikan yang dimasukkan ke dalam perairan tersebut merupakan ikan asli. Melalui restoking diharapkan ukuran populasi ikan sidat akan mengalami peningkatan. Untuk mencapai keberhasilan dalam proses restoking perlu dilakukan dengan prosedur yang baik dan benar. Prosedur yang dimaksud mulai dari kajian lokasi yang akan direstoking, ukuran ikan yang akan ditebar, kondisi ikan harus sehat, dan pemantauan yang dilakukan secara periodik dan terintegrasi dengan para pemangku kepentingan.

Upaya konservasi ditempuh pula melalui pemeliharaan dan perbaikan kondisi habitat ruaya ikan sidat sehingga dapat terjamin keberlanjutannya. Haryono (2008) menyebutkan bahwa pemeliharaan habitat ruaya dapat dilakukan dengan cara menjaga agar tidak terjadi pengendapan dan penutupan muara sungai. Salah satunya adalah dengan menjaga kondisi daerah aliran sungai (DAS) dari penebangan/penggundulan hutan sehingga tingkat erosi dapat ditekan.

Hal yang tidak kalah pentingnya dalam upaya menjaga kelestarian ikan sidat adalah adanya kesepahaman dan perhatian secara lintas sektoral. Selama ini, sumberdaya ikan seringkali terabaikan pada saat penyusunan rencana pembangunan waduk dan pembangkit listrik. Oleh karena itu dalam pembangunan waduk dan pembangkit listrik harus memperhatikan dan memfasilitasi bagi keberlangsungan proses ruaya ikan sidat dan jenis ikan lainnya. Poulsen \& Valbo-
Jorgensen (2000) menyatakan bahwa ruaya merupakan proses penting dalam siklus hidup ikan yang memerlukan adaptasi terhadap kondisi perairan. Selanjutnya Harrisson et al. (2014), bahwa dalam pengelolaan benih sidat harus dilandasi bukti ilmiah terkait siklus hidupnya. Di beberapa tempat telah terjadi pembangunan waduk yang tidak dilengkapi fishway (jalur ikan) sehingga terjadi fragmentasi habitat yang menghambat proses ruayanya. Hal yang sama juga terjadi akibat pembangunan pembangkit listrik tenaga uap (PLTU) yang tepat berada di tepian muara sungai. Untuk dapat memperbaiki kondisi seperti di atas perlu dilakukan perencanaan dan pengelolaan secara terintegrasi.

\section{Kesimpulan}

Habitat ruaya benih sidat banyak tersebar di sepanjang pantai selatan Jawa. Sungai yang potensial sebagai sumber benih sidat adalah Bayah, Cibuni, Cibuniangeun, dan Cikaso. Kondisi habitat ruaya benih sidat di pantai selatan wilayah Jawa Barat dan Banten masih cukup baik. Kelimpahan benih sidat berfluktuasi, pada musim kemarau kelimpahan tertinggi di S. Cibuni dan pada musim penghujan di $S$. Cibuniangeun. Teridentifikasi beberapa aktivitas yang mengancam keberlanjutan ruaya benih sidat. Upaya konservasi sumberdaya ikan sidat perlu dilakukan melalui pengelolaan secara terintegrasi.

\section{Daftar Pustaka}

Aalto, E., Capoccioni, F., Terradez M.J., Schiavina, M., Leone, C., De Leo, G. Ciccotti, E. 2016. Quantifying 60 years ofdeclining Europeaneel (Anguilla Anguilla L.,1758) fishery yields in Mediterranean coastal lagoons. ICES Journal of Marine Science, 73(1): 101-110.

Affandi, R., Rahardjo, M.F. \& Sulistiono. 1995. Distribusi juvenile ikan sidat (Anguilla spp.) di perairan segara anakan Cilacap, Jawa Tengah. Jurnal IImuilmu Perairan dan Perikanan, 3(1): 27-38.

Anonim. 1992. Booklet Masalah Perkotaan dan Lingkungan. Kantor Pengkajian Perkotaan dan Lingkungan (KPPL) DKI Jakarta. 
Charrier, F., Mazel, V., Caraguel, J.M., Abdallah, Y., Le Gurun, L.L., Legault, A., Laffaille P. 2012. Escapement of a silver-phase eel population,Anguilla anguilla, determined from fishery in a Mediterranean lagoon (Or, France). ICES Journal of Marine Science, 69 (1): 30-33.

Davey, A.J.H., Jellyman, D.J. 2005. Sex determination in freswater eels and management options for manipulation. Reviews in fish Biology and fisheries 15: 37-52.

Dou, S.Z., Tsukamoto, K. 2003. Observations on the nocturnal activity and fedding behavior of Anguilla japonica glass eel under laboratory conditions. Environmental Biology of Fishes 67: 389-395.

Effendie, H. 2003. Telaah Kualitas Air Bagi Pengelolaan Sumber Daya Dan Lingkungan Perairan. Penerbit Kanisius, Yogyakarta.

Feunteun, T.R.E. 2002. First observation of shortfinned Anguilla bicolor bicolor and longfinned Anguilla marmorata silver eels in the Reunion Island. Bull. Fr Peche Piscic 364: 87-95.

Harrison, A.J., Walker, A.M., Pinder, A.C., Briand, C., Aprahamian, M.W. 2014. A review of glass eel migratory behaviour, sampling techniques and abundance estimates in estuaries: implications for assessing recruitment, local production and exploitation. Reviews in Fish Biology and Fisheries 24(4): 967-983.

Haryono. 2008. Sidat belut bertelinga: potensi dan aspek budidayanya. Fauna Indonesia 8(1): 22-26.

Haryono, Subagja, J., Wahyudewantoro, G. 2011. Kelangsungan hidup dan perilaku benih sidat (Anguilla bicolor) pada awal pemeliharaan dengan salinitas berbeda. Prosiding Seminar Nasional Ikan VI. Cibinong 8-9 Juni 2010. HIm, 261-266.

Herianti, I. 2005. Rekayasa lingkungan untuk memacu perkembangan ovarium ikan sidat (Anguilla bicolor). Oseanologi dan Limnologi 37: 25-41.
Hernando, A.R. 2007. Sidat santapan kalangan elite Jepang. Bisnis Indonesia terbitan 24 Juli 2007.

Kamil, M.T., Affandi, R., Mokognita, I., Jusadi, D. 2000. Pengaruh kadar asam lemak $\omega 6$ yang berbeda pada kadar asam lemak $\omega 3$ tetap dalam pakan terhadap pertumbuhan ikan sidat (Anguilla bicolor bicolor). Jurnal Central Kalimantan Fisheries 1(1), 34-40.

Keni. 1993. Atraktan dalam pakan sidat. Majalah Perikanan Techner No. 09 September 1993.

Kim, W.S., Yoon, S.J., Kim, J.W. 2006. Metabolic response under different salinity and temperature conditions for glass eel Anguilla japonica. Marine Biology 149: 1209 - 1215.

Linton, E.D.,Jonsson, B., Noakes, D.L.G. 2007. Effects of water temperatur on the swimming and climbing behavior of glass eels, Anguilla sp. Environmental Biology of Fishes 78: 189-192.

Matsui, I. 1982. Theory and practice of eel culture. AA. Balkema, Rotterdam.

Miller, M.J. \& Tsukamoto, K. 2004. An Introduction to Leptocephali Biology and Identification. Ocean Reeserch Institute, The University of Tokyo.

Peni, S.P. 1993. Tiga Jenis Sidat Laku Ekspor. Trubus No. 285 Th.XXIV.

Peraturan Menteri Kelautan dan Perikanan Nomor 18. 2009. Larangan Pengeluaran Benih sidat (Anguilla spp.) dari Wilayah Negara Indonesia ke Luar wilayah Negara Indonesia. Kementerian Kelautan dan Perikanan Republik Indonesia, Jakarta.

Poulsen, A.F., Valbo-Jorgensen, J. 2000. Fish migration and spwaning habits in the Mekong mainstream: A survey using local knowledge. AMFC Technical Report. Vientiane: Mekong River Commission.

Pratiwi, E. 1998. Mengenal lebih dekat tentang perikanan sidat (Anguilla spp.). Warta Penelitian Perikanan Indonesia, 4(4): 8-12.

Sadili, D., Haryono, Kamal, M.M., Sarmintohadi, Ramli, I. 2015. 
Pedoman Umum restoking Jenis Ikan Terancam Punah. Direktorat Konservsi Kawasan dan Jenis Ikan, Kementerian dan Kelautan, Jakarta.

Sarwono, B. 1999. Budidaya Belut dan Sidat. Penebar Swadaya, Jakarta.

Sugeha, H.Y.,Aoyama J. \& Tsukamoto, K. (2006). Downstream migration of tropical anguillid silver eels in the Poso Lake, Central Sulawesi Island, Indonesia. Prosiding Seminar Limnologi, HIm: 267-275.

Sutardjo, Mahfudz. 1972. Percobaan Pendahuluan Penangkapan dan Pengangkutan. Laporan No. 55. Lembaga Penelitian Perikanan Darat, Bogor.

Tesch, E. W. 2003. The eel: Biology and Management of Anguillid Eels. Chapman and Hall, London.

Wahyudewantoro, G., Haryono. Subagja J. 2011. Pengaruh suhu angkut terhadap kelangsungan hidup benih ikan sidat (Anguilla bicolor). Prosiding Seminar Nasional Ikan VI. Cibinong 89 Juni 2010. HIm: 239-245.

Watanebe, S., Aoyama, J., Nishida, M., Tsukamoto, K. 2005. Evaluation of the population structure of Anguilla bicolor bicolor using total number of vertebrae and te mtDNA control region. Coastal Marine Science, 29(2): 165-169. 